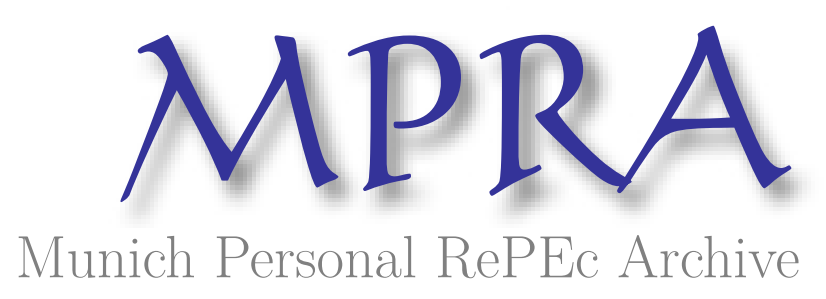

\title{
Decomposition analysis of green chemical technology inventions from 1971 to 2010 in Japan
}

Fujii, Hidemichi and Shirakawa, Seiji

2015

Online at https://mpra.ub.uni-muenchen.de/62790/

MPRA Paper No. 62790, posted 13 Mar 2015 13:32 UTC 


\title{
Decomposition analysis of green chemical technology inventions
}

\section{from 1971 to 2010 in Japan}

\author{
Hidemichi Fujii \\ Graduate School of Fisheries Science and Environmental Studies, Nagasaki University \\ 1-14 Bunkyo-machi, Nagasaki 852-8521, Japan. \\ E-mail: hidemichifujii@nagasaki-u.ac.jp/ Phone: +81-95-819-2756/Fax: +81-95-819-2756
}

\section{Seiji Shirakawa}

Graduate School of Fisheries Science and Environmental Studies, Nagasaki University

\begin{abstract}
Green chemistry plays an important role in achieving sustainable development. This study examines the determinant factors for technology invention related to green chemistry in Japan using patent application data and a decomposition analysis framework. Our main findings are that the number of green chemical technologies applied to production processes have increased because of the scale-up of overall research activities and increased priority. Additionally, the number of patent applications for green chemical technology-related product design and renewable energy increased mainly because of increased research priority. The differences in determinants among types of green chemical technology inventions are useful for formulating an effective policy to promote innovation in green chemical technology.
\end{abstract}

Keywords: green chemistry, decomposition analysis, patent, research and development, Japan 


\section{Introduction}

Chemical substances are extensively applied in production processes in the manufacturing sector and many toxic chemical substances are released outside of the manufacturing plants. Most toxic chemical substances are generated by inefficient use of intermediate chemical materials in the production process (Fujii and Managi, 2013). End-of-pipe (EOP) approach ${ }^{1}$ technologies have been introduced as a toxic chemical pollutant abatement technology. EOP-type approaches are associated with both running costs and initial costs, which reduces the motivation of manufacturing companies to use appropriate pollutant treatment (UNEP, 2013a). As a result, environmental damage, human health hazards, and disruption of ecosystems are caused by the emission of untreated toxic chemical substances (UNEP, 2013b). Additionally, the illegal dumping of plastic products such as plastic bags and plastic bottles also causes a serious impact on fish in their natural environment (Carson, 2013).

However, chemical materials are essential for production processes in the manufacturing sector. Chemical materials are used in applications such as solvents, adhesion, and painting. Additionally, it is difficult to decrease the diffusion of plastic products, which are conveniently used for daily life in human society.

Based on this situation, the necessity to invent environmentally friendly chemical materials is becoming increasingly recognized. In the late 1980s, the International Union of Pure and Applied Chemistry first promoted the idea of green chemistry (Nilsson et al., 2007). According to the United States Environmental Protection Agency (US EPA), green chemistry is defined as "the design of chemical products and processes that reduce or eliminate the generation of hazardous substances". Additionally, the Organization for Economic Cooperation and Development (OECD) defined green chemistry as "the design, manufacture and use of efficient, effective, safe and more environmentally benign chemical products and process" (2011).

\footnotetext{
${ }^{1}$ The EOP approach is based on pollution removal using so-called "filters" in smokestacks or drains. Major EOP technologies include desulfurization and wastewater treatment. However, EOP technology has several defects. EOP treatments cause secondary environmental pollution problems such as the generation of sludge waste through wastewater treatments, and they are also associated with substantial investment in equipment and expensive running costs. EOP treatments do not contribute directly to improving productivity. Because firms perceive the costs of EOP treatments to be an additional expenditure for nonproductive activity, they do not usually have strong incentives for pollution abatement through the EOP approach (Fujii et.al., 2013).
} 
Green chemistry may play a critical role in achieving both environmental protection and economic development (Manley et al., 2008) because it allows manufacturing firms to reduce pollution abatement costs and decrease accidental pollution risk by minimizing toxic chemical substance generation in production processes (Lezano et al., 2013). According to Pike (2011), green chemistry represents a market opportunity that will grow from $\$ 2.8$ billion in 2011 to $\$ 98.5$ billion by 2020 , and green chemicals will save $\$ 65.5$ billion in the industrial sector by 2020 .

However, not all green chemical technology equally contributes to improved financial performance; some green chemical technologies directly contribute to reducing pollution abatement costs, whereas other green chemical technologies contribute indirectly and minimally. Therefore, it is clear that companies' incentives for generating green chemical technology inventions vary different among technology types. A determinant analysis of inventions focusing on the characteristics of each type of green chemical technology is important to suggest an effective policy to encourage research and development in green chemistry. Based on this motivation, the present study focuses on the characteristics of green chemical technology.

However, it is difficult to specify the environmental technologies related to green chemistry (hereafter green chemical technology) under this definition. Thus, we focus on patent application data for five green chemical technologies defined using the international patent classification (IPC) of the OECD (2011). Table 1 describes the summary of the five green chemical technologies.

\section{$<$ Table 1 about here>}

In particular, this study focuses on green chemical technology inventions of Japanese manufacturing companies because, after the US, Japan is the second leading innovator in green chemical technologies in the world (OECD, 2011). Although many studies have addressed green chemical technology, most were conducted on technologies invented in the US and European countries (Nameroff et al., 2004; Lezano et al., 2013). We believe that an empirical study of Japanese manufacturing companies will provide useful information for understanding inventions in green chemical technology around the world. 
Another reason we focused on Japan is the high availability of company-level data in Japan. Previous studies focused on mainly national-level patent data for green chemistry; few studies analyzed company-level data. However, it is clear that business decision-making mechanisms for investing in research and development vary because incentives differ according to the manner of using green chemical technology. Thus, effective policies for promoting green chemical technology invention would be different for different technology types. It is therefore necessary to analyze green chemical technology development by focusing on different types of patents using company-level data.

The objective of this study is to clarify the determinant factors of green chemical patent applications according to type of technology using a dataset of Japanese manufacturing companies. We also discuss how industrial characteristics and environmental regulations affect the invention of green chemical technology in Japan using the company dataset.

The rest of the paper is organized as follows. Section 2 describes our methodology. Section 3 explains the dataset. The results of the green chemistry patent analysis are discussed in Section 4. The paper concludes with Section 5.

\section{Methodology}

We apply a decomposition analysis framework to clarify the changing factors for green chemistry patent application in Japan. To decompose patent applications in green chemistry, we use two indicators: the priority of specific green chemistry (PRIORITY) and the scale of patent applications (SCALE). We define the PRIORITY indicator as the number of specific green chemistry patent applications divided by total number of patent applications, giving the share of specific green chemistry patent applications among total patent applications. This indicator can be increased if the number of specific green chemistry patent applications increases more quickly than the number of total patent applications, thus indicating that inventors concentrate their research resources into green chemical technology invention. Inventors have higher priority to invent green chemistry technology over other types of technology if the PRIORITY is increased. 
The SCALE indicator is defined as the total number of patent applications and thus represents the scale of research and development activities. Generally, active research and development efforts promote the invention of new technologies. Thus, the total number of patent applications reflects the level of active research and development efforts. Additionally, research and development activities in companies depend on the corporate financial situation because patent applications are associated with the cost of the salary of the researchers, the running cost of experimental materials, and cost of applying for the patent. For example, the number of patent applications declined after the financial crisis caused by the collapse of Lehman brothers (OECD, 2009). Thus, companies with deep financial difficulties decided to reduce their research and development activities to reduce their bankruptcy risk. This decrease in research and development activities caused a decline in the number of new patent applications, including those related to green chemistry technologies. Therefore, the scale of research and development activity is an important factor for understanding why the number of green chemistry patent applications has changed. SCALE can be increased if the total number of patent applications increases. The number of patent applications for green chemical technology would be increased by the scale-up of overall research and development activities if the SCALE score increased.

The number of green chemical patent applications (GREEN) is decomposed using the total number of patent applications (TOTAL) as in equation (1).

$$
\text { GREEN }=\text { GREEN } / \text { TOTAL } \times \text { TOTAL }=\text { PRIORITY } \times \text { SCALE }
$$

We consider the green chemistry patent application change from year t-1 (GREEN $\left.{ }^{t-1}\right)$ to year t $\left(\operatorname{GREEN}^{t}\right)$. By using equation (1), the growth ratio of green chemistry patent applications can be represented as follows, where $i$ represents specific green chemistry technology:

$$
\frac{\text { GREEN }_{i}^{t}}{\operatorname{GREEN}_{i}^{t-1}}=\frac{\text { PRIORITY }^{t}}{\text { PRIORITY }^{t-1}} \times \frac{\text { SCALE }^{t}}{\text { SCALE }^{t-1}}
$$


We transform equation (2) to a natural logarithmic function and thus obtain equation (3) 2 .

$$
\operatorname{lnGREEN}_{i}^{t}-\operatorname{lnGREEN}{ }_{i}^{t-1}=\ln \left(\frac{\text { PRIORITY }^{t}}{\text { PRIORITY }^{t-1}}\right)+\ln \left(\frac{\text { SCALE }^{t}}{\text { SCALE }^{t-1}}\right)
$$

Multiplying both sides of equation (3) by $\omega_{i}^{t}=\left(\operatorname{GREEN}_{i}^{t}-\operatorname{GREEN}_{i}^{t-1}\right) /\left(\operatorname{lnGREEN}_{i}^{t}-\right.$ $\operatorname{lnGREEN}_{i}^{t-1}$ ) yields equation (4), as follows. ${ }^{3}$

$$
\operatorname{GREEN}_{i}^{t}-\operatorname{GREEN}_{i}^{t-1}=\Delta \text { GREEN }_{i}^{t, t-1}=\omega_{i}^{t} \ln \left(\frac{\text { PRIORITY }^{t}}{\text { PRIORITY }^{t-1}}\right)+\omega_{i}^{t} \ln \left(\frac{\text { SCALE }^{t}}{\operatorname{SCALE}^{t-1}}\right)
$$

Therefore, changes in number of patent applications of green chemical technology $i\left(\triangle\right.$ GREEN $\left._{i}\right)$ are decomposed by changes in PRIORITY (first term) and SCALE (second term). The term $\omega_{i}^{t}$ operates as an additive weight for the estimated number of patent applications for green chemical technologies. This decomposition technique is called the logarithmic mean Divisia index (LMDI) and was developed by Ang et al. (1998). Ang (2004) noted that LMDI is the preferred method for decomposition analysis because of its theoretical foundation, adaptability, ease of use and result interpretation, and lack of the residual terms generated by Laspeyres-type methodologies.

The novel point of this research is to clarify companies' research and development strategies using LMDI analysis. Many previous studies focused on only the number of patent applications, which is affected by both the priority for inventions and scale of the research activity (Dubarić et al., 2013; Fu et al., 2014). This study attempts to derive pure priority for inventions from patent application data by

\footnotetext{
${ }^{2}$ Zero values in the dataset cause problems in the formulation of the decomposition because of the properties of logarithmic functions. To solve this problem, the literature on LMDI suggests replacing zero values with a small positive number (Ang and Liu, 2007).

${ }^{3} \omega_{i}^{t}=0$ if GREEN ${ }_{i}^{t}=$ GREEN $_{i}^{t-1}$.
} 
controlling for the scale effect. This is the first study to apply a decomposition framework to patent data analysis.

\section{Data}

We used patent application data from the patent database published by the Institute of Intellectual Property (IIP) (Goto and Motohashi, 2007). The IIP Patent database covers 12,367,268 patent applications from 1964 to $2012^{4}$. We specified green chemical technology patents following OCED (2011). As explained above, this study focuses on five green chemistry technologies: (1) biochemical fuel cells (fuel), (2) biodegradable packaging (package), (3) selected white biotechnology (biotech), (4) aqueous solvents (solvent), and (5) totally chlorine-free bleaching technologies (TCF).

In previous research, patent data were mainly applied to two methods of analysis. The first method used the number of patents granted (Pop, 2006; Kinbara, 2013), which represents the number of patent applications with sufficient quality to pass the examination. This method is mainly applied to examine the diffusion of technologies. However, these data do not include information regarding patent applications that do not pass the examination. Thus, the data on granted patents do not cover the inventors' research and development strategy and activities.

The other method utilizes patent application data (Dubarić et al., 2013; Fu et al., 2014). Patent application data can reflected inventors' research and development activities. However, some of these patent applications do not pass the examination process, which suggests that the quality of the invention is insufficient. Additionally, an application fee is required for the patent application procedure. Thus, inventors likely are confident that their invention will pass the examination process if they submit a new patent application. Therefore, we believe that patent application data reflect inventors' research and development activities and strategies to a greater extent than data on granted patents. We therefore used patent application data to represent inventors' research and development strategies for green chemistry technologies.

\footnotetext{
${ }^{4}$ The patent database was constructed using standardized data from the Japan Patent Office through its 25 th release.
} 
Figure 1 shows the trend for patent applications for green chemical technologies in Japan from 1971 to 2010 . Table 2 summarizes the environmental regulations related to toxic chemical substances. Figure 1 shows that the number of patent applications in green chemical technology increased from 1978 because of the growth of patent applications related to white biotechnologies.

After the number of patent applications decreased in the 1990s, it increased again in the 2000s. White biotechnologies comprised the majority of patent applications in the 1980s. The number of applications related to totally chlorine-free (TCF) bleaching, aqueous solvents, and biodegradable packaging technologies increased in the 1990s. Biochemical fuel cell technology was actively researched after 2003.

$<$ Figure 1 about here >

$<$ Table 2 about here>

Here, we explain the trend for green chemical patent applications by type of industry. Table 3 shows the number of green chemical patent applications for each industry from 1971 to 2010. The Japan Standard Industrial Classification (JSIC) was used to categorize the industry type ${ }^{5}$. Table 3 shows that the industrial characteristics strongly affected the patent application trend.

$<$ Table 3 about here>

\section{Result}

Figures 2 to 6 show the trends for patent applications related to green chemical technology. The plotted line shows the number of patent applications, and the bar chart shows the effects of each factor on the number of patent applications related to green chemical technology ${ }^{6}$. The sum of the bars is

\footnotetext{
${ }^{5}$ Detailed information regarding JSIC is presented on the home page of the Ministry of Internal Affairs and Communications. (http://www.soumu.go.jp/english/dgpp_ss/seido/sangyo/index.htm)

${ }^{6}$ The score of the vertical line standardized by the number of patent applications from 1971 to 1975 year is equal to zero. From Figure 1 , the number of green chemistry patent applications from 1971 to 1975 was close to zero. The negative value of the line indicates that the number of patent applications was lower than that from 1971 to 1975.
} 
equivalent to the value of the plotted line. The figures show the differences in the determinant factors for patent applications according to the type of green chemical technology. We divided the whole period of analysis into eight periods with five-year intervals to facilitate the discussion of the results. We then examined whether the pattern of technology development varied among these time periods.

Table 4 lists the companies filing green chemical patent applications from 1971 to $2010{ }^{7}$ Table 4 shows that the top three companies contributed only $20 \%$ of the applications in biodegradable packaging technology and $10 \%$ of the applications in selected white biotechnology applications. This small share of the top three companies implies that green chemical patent applications are filed by many inventors in many fields. However, the top three companies filed more than $40 \%$ of the applications in the other three types of technology, including nearly $60 \%$ of patent applications on biochemical fuel cells.

$<$ Table 4 about here>

$<$ Figure 2 about here>

Here, we discuss the results of the decomposition analysis using the figures and Table 4. Figure 2 shows that the amount of biodegradable packaging technology patent applications increased in the 1990s and 2000s because of priority placed on this field. However, the effect of research and development scale was low in all periods. These results imply that the invention of biodegradable packaging technology strongly depends on the prioritization by the inventors but not the scale of research and development activities.

One interpretation of these results is that the cost of biodegradable packaging products is higher than that of conventional packaging products. Companies will not decide to invent new technologies

\footnotetext{
${ }^{7}$ If more than two third-ranking companies were present, we listed all third-ranking companies in Table 4.
} 
that are unlikely to produce profit in the market even if the scale of the research budget is expanded. However, the number of patent applications increased rapidly because of increased priority from 1991 onward. One interpretation of this change is that it resulted from enforcement of environmental regulations regarding packaging in Japan. ${ }^{8}$ These environmental laws encouraged manufacturing firms to save and recycle resources. Simultaneously, new environmentally friendly packaging technologies and products were strongly demanded in the market. Thus, firms producing packages had a high incentive to invent new biodegradable packaging technologies after 1991.

Table 4 shows that printing companies submitted the most patent applications for biodegradable packaging in Japan, which is logical because packaging of products is a core operation for the printing industry. Therefore, the printing industry attempted to meet the demand for environmentally products in the market through the invention of new biodegradable packaging technologies. Toppan Printing Co., Ltd. produced a unique integrated circuit card called the KAMICARD, which was made from recyclable and biodegradable paper and thus introduced an ecological solution to ID security and payment media (Toppan printing Co. Ltd., 2009). Toppan Printing Co., Ltd. noted that increased usage of the KAMICARD contributed to a reduction of $\mathrm{CO}_{2}$ emissions and reduction of petroleum material consumption required to produce plastic.

$<$ Figure 3 about here>

Next, we consider patent applications regarding aqueous solvents. Figure 3 shows that the number of patent applications regarding aqueous solvents increased from 1986 onward as a result of both increased priority and a scale effect. Fujii (2011) noted that the pollution release and transfer registers law (PRTR law) provided a strong incentive for manufacturing firms to decrease their production of

\footnotetext{
${ }^{8}$ The law for the promotion of the utilization of recycled resources was enforced starting in 1991. The law for the promotion of sorted collection and recycling of containers and packaging was enacted in 1995 (see Table 2).
} 
toxic chemical substances because information disclosure regarding toxic chemical substances enabled stakeholders to understand the risk of environmental accidents at the manufacturing plants. Thus, manufacturing firms replaced highly toxic chemical materials with low-toxicity chemical substances in their production processes. Based on this situation, new environmentally friendly solvents were strongly demanded in the market, which caused chemical companies to promote the research and development of aqueous solvents.

After the number of patent applications rapidly decreased from 2001 to 2005, it increased again from 2006 to 2010 . One interpretation of the change in the priority given to aqueous solvents is that it was affected by environmental regulations regarding volatile organic compounds (VOC). ${ }^{9}$ Increased use of aqueous solvents is a solution to decrease VOC emissions. Another factor is the increasing number of aqueous solvent patent applications by foreign chemical companies. Table 4 shows that the second largest patent applicant in terms of number of applications filed is BASF SE, which is an international chemical company headquartered in Germany. BASF SE applied for 14 patents on aqueous solvents in Japan from 1971 to 2010; in particular, 9 patent applications were filed after 2007. The European Union enforced several environmental regulations on air quality management,${ }^{10}$ which gave the incentive for chemical companies in the EU to invent new solvent technologies. Additionally, international companies have a business strategy to apply for green chemical patents in foreign countries where environmental regulations would become stricter in the future.

Table 3 and Table 4 show that aqueous solvent patent applications were mainly filed by the chemical industry and that the nationalities of the companies were diverse. Thus, aqueous solvent patent applications in Japan were filed as part of an international development race.

<Figure 4 about here>

\footnotetext{
${ }^{9}$ Usually, oil paint is used in painting processes in manufacturing companies. However, the use of oil paint generates VOC substances. As a result, VOC emission increases, oxidase smog is generated and the amount of suspended particulate matter (SPM) increases.

${ }^{10}$ For example, Directive 2008/50/EC of the European Parliament and of the Council of 21 May 2008 on ambient air quality and clear air for Europe (EU).
} 
Figure 4 shows that the number of patent applications on selected white biotechnologies increased from 1976 to 1985 . This patent application growth is caused by the international oil price increase caused by the oil shock of 1973 and 1979. Japanese manufacturing firms tried to invent alternative energy technologies to prevent increases in energy costs for production. In these periods, chemical and food companies invented new energy technologies focusing on the transformation from starch sugar to ethanol and methane.

The number of patent applications on selected white biotechnology gradually decreased after 1990 as a result of decreased priority because the international oil price was stable from 1991 to 2003. However, the number of patent applications increased after 2006 because of increased priority. There are two reasons why companies shifted their research strategy to set a high priority on selected white biotechnology. First, the international oil price increased rapidly after 2004. The international oil price increase encouraged chemical companies to invent alternative energy technologies using fermentation and non-fossil fuels (e.g., large-scale biomass power generation). Second, the application scope of white biotechnology expanded to chemical material extraction from woody biomass (Liu, 2010). Here, we introduce a case study regarding Kaneka Corp., which is the second largest company in Japan with regard to filing selected white biotechnology patent applications (see Table 4).

Kaneka Corp. produces the world's first completely bio-based polymer made by woody biomass and vegetable fats and oils ${ }^{11}$. Thus, selected white biotechnology is applied to not only alternative energy technology but also new material inventions. Table 4 shows that the contribution of the top three companies to selected white biotech patent applications is below $10 \%$, which is much lower than the corresponding proportion in other green chemical technologies, thus implying that selected white biotechnology is invented by many companies in many industries because of the wide scope of applications.

\footnotetext{
${ }^{11}$ Detailed information is provided by the Kaneka Corp. homepage http://www.kaneka.co.jp/kaneka-e/branch/nb_development/.
} 
$<$ Figure 5 about here>

Figure 5 shows that the number of patent applications for TCF bleaching technologies increased after 1976. In this period, environmental regulation for wastewater quality become stricter. Additionally, the number of patent applications rapidly increased from 1991 to 1995 . The rapid increase in the number of patent applications was caused by voluntary regulation in the pulp and paper industry ${ }^{12}$. Because of the intensive research and development activities for TCF bleaching technology in this period, the number of patents nearly tripled from those of previous periods.

Table 3 shows that TCF bleaching technologies were mainly invented by the pulp and paper industry and the chemical industry. Table 4 shows that Oji Holdings Corporation contributed more than one fourth of the patent applications on TCF bleaching technologies in Japan. Additionally, Oji Holdings Corporation invented new bleaching technologies using peroxymonosulfuric acid together with Mitsubishi Gas Chemical Company, Inc., which is the second largest patent applicant in Japan (Koshitsuka, 2011; Ogawa, 2012). These findings indicate that the joint research group from these two companies was the leading innovator in TCF bleaching technologies in Japan from 1971 to 2010.

$<$ Figure 6 about here>

Finally, we discuss patent applications on biochemical fuel cell technologies. Figure 6 shows that biochemical fuel cells were not invented actively before 2000. However, the number of patent applications rapidly increased because of increased priority after 2001 in Japan. Table 3 shows that the

\footnotetext{
${ }^{12}$ According to McLeod et.al. (1995), a high concentration of dioxin was detected in fish in a coastal river in Ehime prefecture in Japan. Additionally, a paper mill plant was identified as the source of the dioxin. To prevent environmental pollution by wastewater from paper mills, the Japan Paper Association (JPA) set guidelines and voluntary regulation of emission targets as less than the adsorbable organohalogen compound level, i.e., $1.5 \mathrm{~kg}$ per ton of bleached pulp, before the end of 1993 (Japan Paper Association, 1997).
} 
main contributor to patent application growth was the processing and assembly industry companies. The reasons the number of patent applications rapidly increased after 2001 include (1) restrictions on the use of rare metals and (2) pressure from stakeholders to reduce GHG emissions. Regarding the restriction of the use of rare metals, high-quality batteries require the use of rare metals. However, after China, which is the largest rare metal producer, initiated rare earth export policies in 2004, Japanese companies have experienced difficulty in import rare metals at the previous prices (Zhang et al., 2015). To bypass the procurement problems associated with rare metals, Japanese manufacturing firms tried to invent new battery technologies using biochemical fuel cells. Another merit of biochemical fuel cells is decreased dependency on fossil fuels, which is contributes to the creation of a low-carbon society.

Table 4 shows that Sony Corporation and Toyota Motor Corporation, whose products required batteries, invented biochemical fuel cells after 2000; in particular, Sony Corporation contributed more than one third of the patent applications in Japan. The second-ranked company, Kurita Water Industries Ltd. has a technological advantage for wastewater treatment, which is a key point in understanding the effect of organic materials and bacterial interactions.

The contribution of the scale effect is larger in Figures 3, 4 and 5 than in Figures 2 and 6. The common point of the three technologies described in Figures 3,4 and 5 is that they are pollution abatement methods that apply cleaner production technologies in production processes ${ }^{13}$. Environmentally friendly solvent and bleaching technologies decrease the risk of environmental accidents. Additionally, white biotechnology enables manufacturing firms to decrease their dependency on petroleum products in their intermediate products.

The figures show that green chemical technologies applied to production processes tended to experience a large effect of scale with regard to changes in the number of patent applications from 1971 to 2010. These results imply that the increase in the number of green chemical patent applications related to production processes was affected by both the scale-up of overall research and development activities and increased priority. One interpretation of this finding is that industrial production processes

\footnotetext{
${ }^{13}$ The cleaner production approach is defined as 'the continuous application of an integrated preventive environmental strategy applied to processes, products, and services to increase overall efficiency, and reduce risks to humans and the environment' (UNEP, 2006).
} 
comprise a large number of technologies. Thus, a new production process is invented as a result of the scale-up of research and development activities, and green chemical technologies are also needed for the new production method. In contrast, biodegradable packaging and biochemical fuel cell technologies are mainly used for environmentally friendly product design and renewable energy sources, respectively.

\section{Conclusions}

This study examined the determinant factors for green chemical patent applications in Japan from 1971 to 2010 . We focused on five green chemical technologies: biodegradable packaging, aqueous solvents, selected white biotechnology, totally chlorine-free bleaching, and biochemical fuel cells. Aqueous solvents, selected white biotechnology, and totally chlorine-free bleaching technologies are mainly applied in production processes in manufacturing sectors. Biodegradable packaging is used for environmentally friendly product design, and biochemical fuel cells are used for fuel batteries with low carbon emissions and to save rare metal resources. We clarified the determinant factors for patent applications covering these five technologies by applying a log-mean decomposition analysis. We obtained the following results.

First, the number of patent applications for green chemical technologies applied in production processes increased because of a scale-up of research activities and increased research prioritization. These results imply that policies that promote overall research and development activities are effective in enhancing the invention of green chemical technologies applied to production processes for pollution prevention. Thus, governments need to understand the indirect effect of policies promoting overall research activities (e.g., tax cut policies for research and development expenditure) to increase the invention of green chemical technologies.

Second, the number of patent applications for green chemical technologies related to product design and renewable energy were mainly increased by increased research prioritization. This finding indicates that these two technologies strongly depend on external factors such as market demand and energy cost and not on internal factors such as pollution abatement cost and risk of environmental 
accidents. Thus, companies increased their research prioritization for these two technologies if they believed that the invented technology would play an important role in future markets. Therefore, a specific research policy is more effective in encouraging corporate invention of biodegradable packaging and biochemical fuel cell technologies than a policy for overall research activities.

As mentioned above, the objectives for inventing green chemical technology are diverse. It is clear that companies have different motivations to invent different types of green chemical technologies. Additionally, the determinant factors for the invention of green chemical technologies also vary according to the type of technology. Based on this background, we examined the determinant factor for green chemical patent applications. This is the first study to evaluate green chemical patent applications using decomposition analysis and numerical data. The comparison of the scale effect and prioritization of research activities is a useful tool to understand changes in patent application filing. 


\section{References}

Ang, B.W. (2004). Decomposition analysis for policymaking in energy: which is the preferred method? Energy Policy 32, 1131-1139.

Ang, B.W., Liu, N. (2007). Handling zero values in the logarithmic mean Divisia index decomposition approach. Energy Policy 35(1), 238-246.

Ang, B.W., Zhang, F.Q., Choi, K.H. (1998). Factorizing changes in energy and environmental indicators through decomposition. Energy 23, 489-495.

Carson, H.S. (2013). The incidence of plastic ingestion by fishes: From the prey’s perspective. Marine Pollution Bulletin 74(1), Pages 170-174.

Dubarić, E., Giannoccaro, D., Bengtsson, R., Ackermann, T. (2011) Patent data as indicators of wind power technology development. World Patent Information 33(2), Pages 144-149.

Fu, B.R., Hsu, S.W., Liu, C.H., Liu, Y.C. (2014) Statistical analysis of patent data relating to the organic Rankine cycle. Renewable and Sustainable Energy Reviews 39, Pages 986-994

Fujii, H., Iwata, K., Kaneko, S., Managi, S. (2013) Corporate environmental and economic performances of Japanese manufacturing firms: Empirical study for sustainable development. Business Strategy and the Environment 22(3), pp. 187-201.

Fujii, H., Managi, S. (2013) Decomposition of toxic chemical substance management in three U.S. manufacturing sectors from 1991 to 2008. Journal of Industrial Ecology 17(3), pp. 461-471.

Fujii, H., Managi, S., Kawahara, H. (2011) The Pollution Release and Transfer Register system in the U.S. and Japan: An analysis of productivity. Journal of Cleaner Production 19(12) pages 1330-1338.

Goto, A., Motohashi, K. (2007) Construction of a Japanese Patent Database and a first look at Japanese patenting activities. Research Policy 36(9), Pages 1431-1442.

Japan Paper Association (1997). Result of Dioxin Prevention Measures of Pulp and Paper Industries in Japan. Japan Tappi Journal. 51 (4) Pages. 595-603. 
Kinbara, T., Fujii, H., Kaneko, S. (2013) Analysis of Environmental Patents in Japan from 1964 to 2008. International Business Research 6(1), pp.145-152.

Koshitsuka, O. (2011). On-site Production of New Bleaching Agent "Peroxymonosulfuric Acid" and Application of It to Pulp Bleaching. JAPAN TAPPI JOURNAL 65(9) Page. 912-918

Liu, S., (2010). Woody biomass: Niche position as a source of sustainable renewable chemicals and energy and kinetics of hot-water extraction/hydrolysis. Biotechnology Advances 28(5), Pages 563582.

Lozano, R., Carpenter, A., Satric, B. (2013). Fostering green chemistry through a collaborative business model: A Chemical Leasing case study from Serbia. Resources, Conservation and Recycling 78, Pages 136-144.

Manley, J.B., Anastas, P.T., Cue, B.W. Jr. (2008). Frontiers in Green Chemistry: meeting the grand challenges for sustainability in R\&D and manufacturing. Journal of Cleaner Production, 16(6), Pages 743-750.

McLeod, C.A., Terasawa, M., Yamamura, E. (1995). International environmental management imbalance. Journal of Environmental Management. 45, pages 45-71.

Nameroff, T.J., Garant, R.J., Albert, M.B. (2004) Adoption of green chemistry: an analysis based on US patents. Research Policy, 33(6-7), Pages 959-974.

Nilsson, L., Persson, P.O., Rydén, L., Darozhka, S., Zaliauskiene, A. (2007). Cleaner Production: Technology and tool for resource efficient production. The Baltic University Environmental Management book series, Baltic University Press, Uppsala.

Organization for Economic Development and Cooperation (OECD) (2011). OECD studies on Environmental Innovation: Chapter 5 Invention and Transfer of Environmental technologies. pp.151-185, OECD, Paris.

Organization for Economic Development and Cooperation (OECD) (2009). Policy Responses to the Economic Crisis: Investing in Innovation for Long-term Growth, pp. 1-39. OECD, Paris. 
Ogawa, Y. (2012). Operating Experience of ECF Bleaching:-Application of Peroxymonosulfuric Acid Bleaching into Mill Scale-. JAPAN TAPPI JOURNAL 66(1) Page. 48-51.

Pike research (2011) “Green Chemicals Will Save Industry $\$ 65.5$ Billion by 2020”. Press release on November 1, 2011. http://www.navigantresearch.com/newsroom/green-chemicals-will-saveindustry-65-5-billion-by-2020

Pop, D., (2006) International innovation and diffusion of air pollution control technologies: the effects of NOX and SO2 regulation in the US, Japan, and Germany. Journal of Environmental Economics and Management 51(1), Pages 46-71.

Toppan Printing Co. Ltd. (2009). The development of the "KAMICARD" IC card made from recyclable and biodegradable paper: Introducing the ecological solution to ID security and payment media. News release, http://www.toppan.co.jp/en/news/2009/02/newsrelease883.html.

United Nations Environment Program (UNEP). (2006). Environmental Agreements and Cleaner Production, UNEP, Geneva.

United Nations Environment Programme (UNEP) (2013a) UNEP Year Book 2013: Emerging issues in our global environment, Geneva.

United Nations Environment Programme (UNEP) (2013b) Cost of inaction on the sound management of chemicals, Geneva.

Zhang, L., Guo, Q., Zhang, J., Huang, Y., Xiong, T. (2015). Did China's rare earth export policies work? — Empirical evidence from USA and Japan. Resources Policy 43, Pages 82-90. 
Table 1 . Green chemistry patent group

\begin{tabular}{ll}
$\begin{array}{l}\text { Green chemistry } \\
\text { patent area }\end{array}$ & \multicolumn{1}{c}{ Description of patent group } \\
\hline $\begin{array}{l}\text { Biodegradable } \\
\text { packaging } \\
(\text { IPC }=\text { B65D65/46) }\end{array}$ & $\begin{array}{l}\text { Biodegradable packaging covers packaging that involve disintegrable, dissolvable or } \\
\text { edible materials and thus are designed so they do not accumulate in the environment. }\end{array}$ \\
\hline & $\begin{array}{l}\text { Many solvents are damaging to the environment (from water to the ozone layer) and } \\
\text { harmful to humans. Organic solvents are prevalent in paint thinners, nail polish } \\
\text { removers, glue solvents, industrial and household cleaning products, printing inks and } \\
\text { inc }=\text { C08F2/10) }\end{array}$ \\
& $\begin{array}{l}\text { solvents with aqueous solvents along with supercritical fluids, ionic liquids or by } \\
\text { using solvent-free processes. }\end{array}$ \\
\hline
\end{tabular}

\begin{tabular}{ll}
$\begin{array}{l}\text { Selected White } \\
\text { Biotech } \\
\text { (IPC = C12P7) }\end{array}$ & $\begin{array}{l}\text { This falls into the white biotechnology/catalysis area and involves the preparation of } \\
\text { oxygen containing compounds using fermentation (or similar). }\end{array}$ \\
\hline $\begin{array}{l}\text { TCF Bleaching } \\
\text { Technologies } \\
\text { (IPC = D21C9/153 }\end{array}$ & $\begin{array}{l}\text { Totally chlorine-free (TCF) bleaching technologies used in the pulp paper industry } \\
\text { remove dioxins found in both paper products and wastewater when using pre-existing } \\
\text { technologies. TCF technologies involve no chlorine compounds and remove all but }\end{array}$ \\
\hline naturally present adsorbable organic halides (AOX), dioxins and furans. \\
Biochemical Fuel & $\begin{array}{l}\text { Biochemical fuel cells, also known as microbial fuel cells (MFCs), derive a current } \\
\text { from bio-electrochemical systems that mimic bacterial interactions. They are a clean } \\
\text { and }\end{array}$ \\
(IPC = H01M8/16) & $\begin{array}{l}\text { and efficient way of producing energy. Many organic materials can be used to feed } \\
\text { the fuel cell including waste material such as wastewater. }\end{array}$
\end{tabular}

Source: OECD (2011) 
Table 2. History of laws and regulations regarding chemical substances in Japan

\begin{tabular}{|c|l|}
\hline Year & \multicolumn{1}{|c|}{ Laws and regulations regarding chemical substances } \\
\hline-1985 & $\begin{array}{l}\text { - Basic Law for Environmental Pollution Control (1967) } \\
\text { - Air Pollution Control Law (1968) } \\
\text { - Water Pollution Control Law (1970) } \\
\text { - Chemical Substances Control Law (1973) }\end{array}$ \\
\hline $1985-$ & $\begin{array}{l}\text {-Amendment of Chemical Substances Control Law (start restriction of chlorinated } \\
\text { organic solvents) (1986) }\end{array}$ \\
\hline $1989-$ & $\begin{array}{l}\text { - Japan Paper Association set guidelines for dioxin measurement and prevention (1990) } \\
\text { - Law for the Promotion of Utilization of Recycled Resources (1991) }\end{array}$ \\
\hline 1994 & $\begin{array}{l}\text { - Basic Environment Law (1993) } \\
\text { - The Basic Environmental Plan (define concept of environmental risk) (1994) }\end{array}$ \\
\hline $1999-$ & $\begin{array}{l}\text { - Law for Promotion of Sorted Collection and Recycling of Containers and Packaging } \\
\text { 1995) }\end{array}$ \\
\hline $2000-$ & $\begin{array}{l}\text { - Pollutant Release and Transfer Registers Law (PRTR Law) (1999) } \\
\text { - Law Concerning Special Measures against Dioxins (2000) } \\
\text {-Amendment of Chemical Substances Control Law (introduced concept of } \\
\text { environmental risk impact into ecological system) (2003) }\end{array}$ \\
\hline 2009 & $\begin{array}{l}\text { - Amendment of Air Pollution Control Law (start restriction of VOC emission) (2006) } \\
\text { - Marking for the presence of specific chemical substances for electrical and electronic } \\
\text { equipment was started (2006) }\end{array}$ \\
\hline
\end{tabular}


Table 3. Trend of patent application by type of industry

\begin{tabular}{|c|c|c|c|c|c|c|c|}
\hline Technology & Industry type [JSIC code] & $\begin{array}{c}1971- \\
1980\end{array}$ & $\begin{array}{c}1981- \\
1990\end{array}$ & $\begin{array}{l}1991- \\
2000\end{array}$ & $\begin{array}{l}2001- \\
2010\end{array}$ & $\begin{array}{l}1971- \\
2010\end{array}$ & Share \\
\hline \multirow{4}{*}{$\begin{array}{l}\text { Biodegradable } \\
\text { packaging }\end{array}$} & Chemicals [16] & 0 & 2 & 19 & 19 & 40 & $27 \%$ \\
\hline & Printing [15] & 0 & 0 & 4 & 13 & 17 & $11 \%$ \\
\hline & Pulp and paper [14] & 0 & 0 & 4 & 9 & 13 & $9 \%$ \\
\hline & Total & 0 & 6 & 55 & 88 & 149 & $100 \%$ \\
\hline \multirow{5}{*}{$\begin{array}{l}\text { Aqueous } \\
\text { solvents }\end{array}$} & Chemicals [16] & 8 & 9 & 31 & 39 & 87 & $69 \%$ \\
\hline & Textile [11] & 1 & 0 & 2 & 2 & 5 & $4 \%$ \\
\hline & Petroleum and coal [17] & 0 & 0 & 3 & 0 & 3 & $2 \%$ \\
\hline & Production machinery [26] & 0 & 0 & 3 & 0 & 3 & $2 \%$ \\
\hline & Total & 12 & 19 & 48 & 47 & 126 & $100 \%$ \\
\hline \multirow{4}{*}{$\begin{array}{l}\text { Selected } \\
\text { white } \\
\text { biotech }\end{array}$} & Chemicals [16] & 72 & 431 & 320 & 351 & 1174 & $34 \%$ \\
\hline & Food [9] & 22 & 121 & 75 & 54 & 272 & $8 \%$ \\
\hline & Textile [11] & 2 & 46 & 39 & 55 & 142 & $4 \%$ \\
\hline & Total & 197 & 1271 & 903 & 1122 & 3493 & $100 \%$ \\
\hline TCF & Pulp and paper [14] & 6 & 12 & 33 & 39 & 90 & $35 \%$ \\
\hline \multirow{3}{*}{$\begin{array}{l}\text { bleaching } \\
\text { technologies }\end{array}$} & Chemicals $[16]$ & 10 & 7 & 11 & 17 & 45 & $18 \%$ \\
\hline & General-purpose machinery [25] & 0 & 0 & 4 & 0 & 4 & $2 \%$ \\
\hline & Total & 29 & 54 & 103 & 70 & 256 & $100 \%$ \\
\hline \multirow{5}{*}{$\begin{array}{l}\text { Biochemical } \\
\text { fuel } \\
\text { cells }\end{array}$} & Electrical products [29] & 1 & 0 & 1 & 40 & 42 & $33 \%$ \\
\hline & Production machinery [26] & 0 & 0 & 0 & 21 & 21 & $16 \%$ \\
\hline & General-purpose machinery [25] & 0 & 1 & 0 & 8 & 9 & $7 \%$ \\
\hline & Transportation equipment [31] & 0 & 1 & 0 & 8 & 9 & $7 \%$ \\
\hline & Total & 3 & 4 & 3 & 0 & 129 & $100 \%$ \\
\hline
\end{tabular}


Table 4. Company list of large green chemical patent application from 1971-2010

\begin{tabular}{|c|c|c|c|}
\hline Technology & Company name [industry type] & $\begin{array}{l}\# \text { of patent } \\
\text { application }\end{array}$ & Share \\
\hline \multirow{3}{*}{$\begin{array}{c}\text { Biodegradable } \\
\text { packaging }\end{array}$} & Toppan printing Co., Ltd. [Printing] & 12 & $8.05 \%$ \\
\hline & Mitsubishi plastic Inc. [Chemicals] & 9 & $6.04 \%$ \\
\hline & Oji Holdings Corporation [Pulp and paper] & 6 & $4.03 \%$ \\
\hline \multirow{3}{*}{$\begin{array}{l}\text { Aqueous } \\
\text { solvents }\end{array}$} & Nippon shokubai Co., Ltd. [Chemicals] & 31 & $24.60 \%$ \\
\hline & BASF SE [Chemicals] & 14 & $11.11 \%$ \\
\hline & Toagosei Co., LTD. [Chemicals] & 12 & $9.52 \%$ \\
\hline Selected & Mitsubishi Chemical Corp. [Chemicals] & 119 & $3.41 \%$ \\
\hline White & Kaneka Corp. [Chemicals] & 113 & $3.24 \%$ \\
\hline biotech & Kao Corp. [Chemicals] & 91 & $2.61 \%$ \\
\hline TCF & Oji Holdings Corporation [Pulp and paper] & 70 & $27.34 \%$ \\
\hline bleaching & Mitsubishi gas chemical company, Inc. [Chemicals] & 28 & $10.94 \%$ \\
\hline technologies & Nippon paper industries Co., Ltd. [Pulp and paper] & 10 & $3.91 \%$ \\
\hline Biochemical & Sony Corporation [Electrical products] & 48 & $37.21 \%$ \\
\hline fuel & Kurita water industries Ltd. [Production machinery] & 20 & $15.50 \%$ \\
\hline cells & Toyota Motor Corporation [Transportation equipment] & 9 & $6.98 \%$ \\
\hline
\end{tabular}




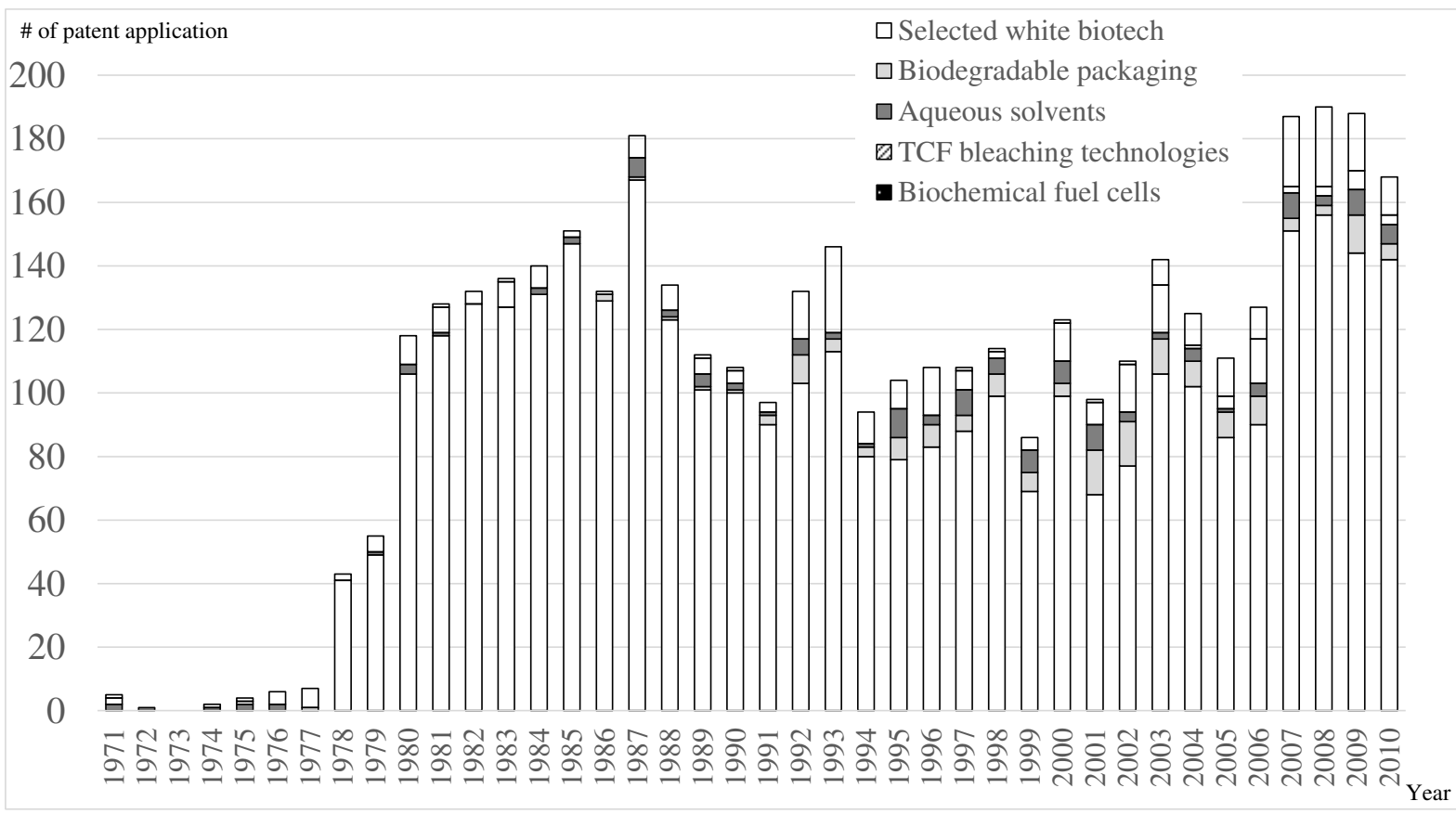

Figure 1. Trend of green chemistry patent applications in Japan

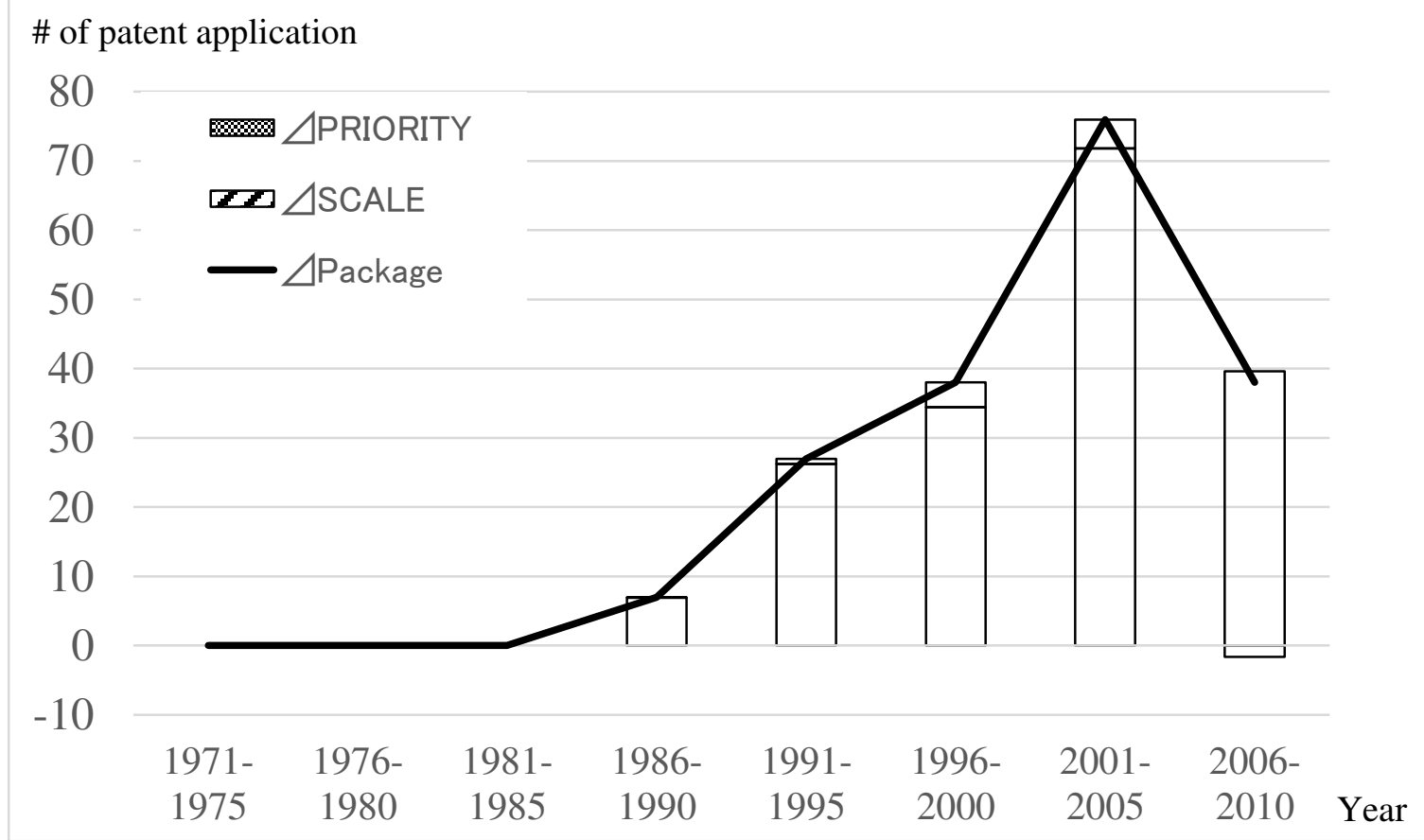

Figure 2. Decomposition analysis of patent applications on biodegradable packaging

Note: The score of the columns is standardized by setting the number of patent applications from 1971 to 1975 to zero. 


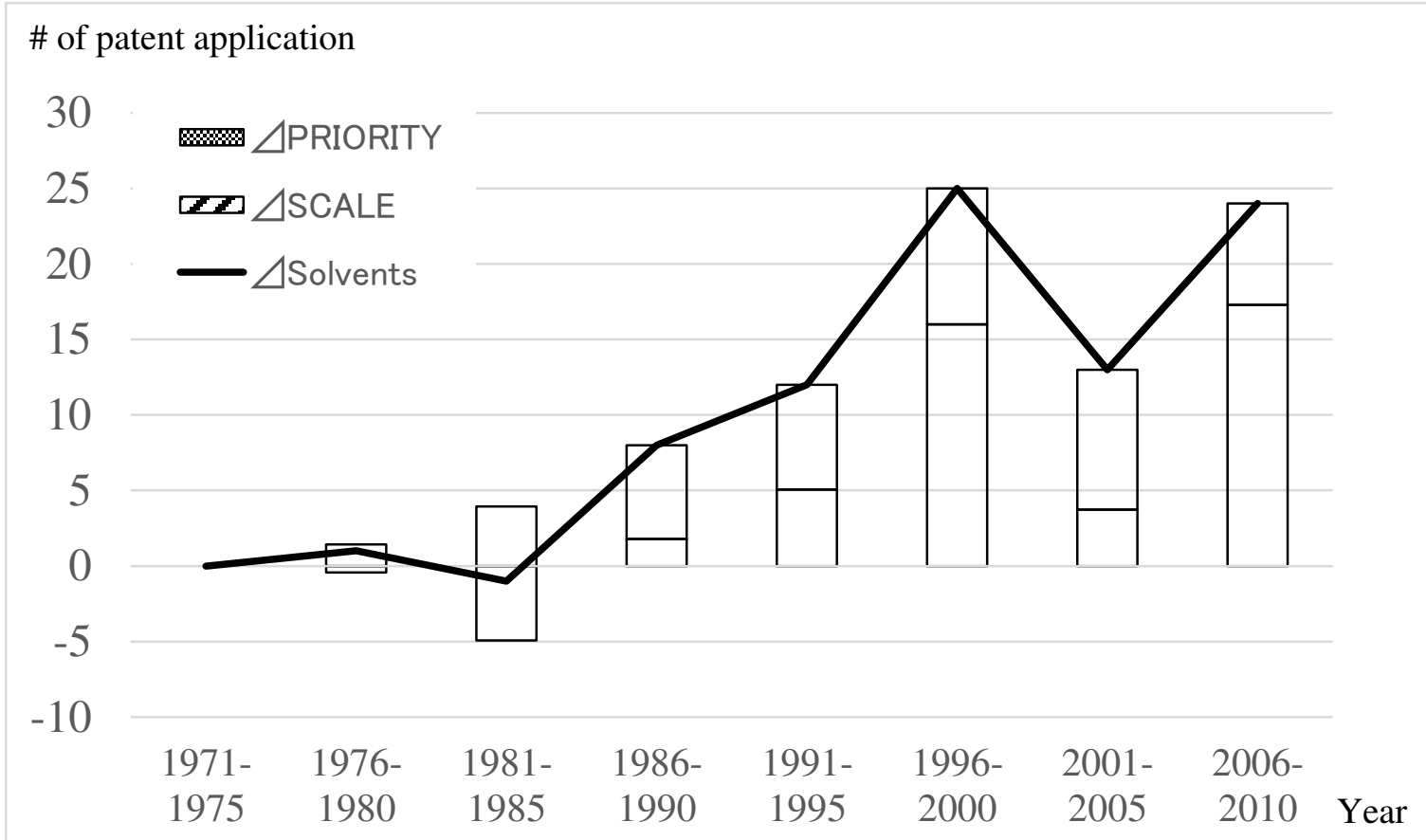

Figure 3. Decomposition analysis of patent applications on aqueous solvents

Note: The score of the columns is standardized by setting the number of patent applications from 1971 to 1975 to zero. 


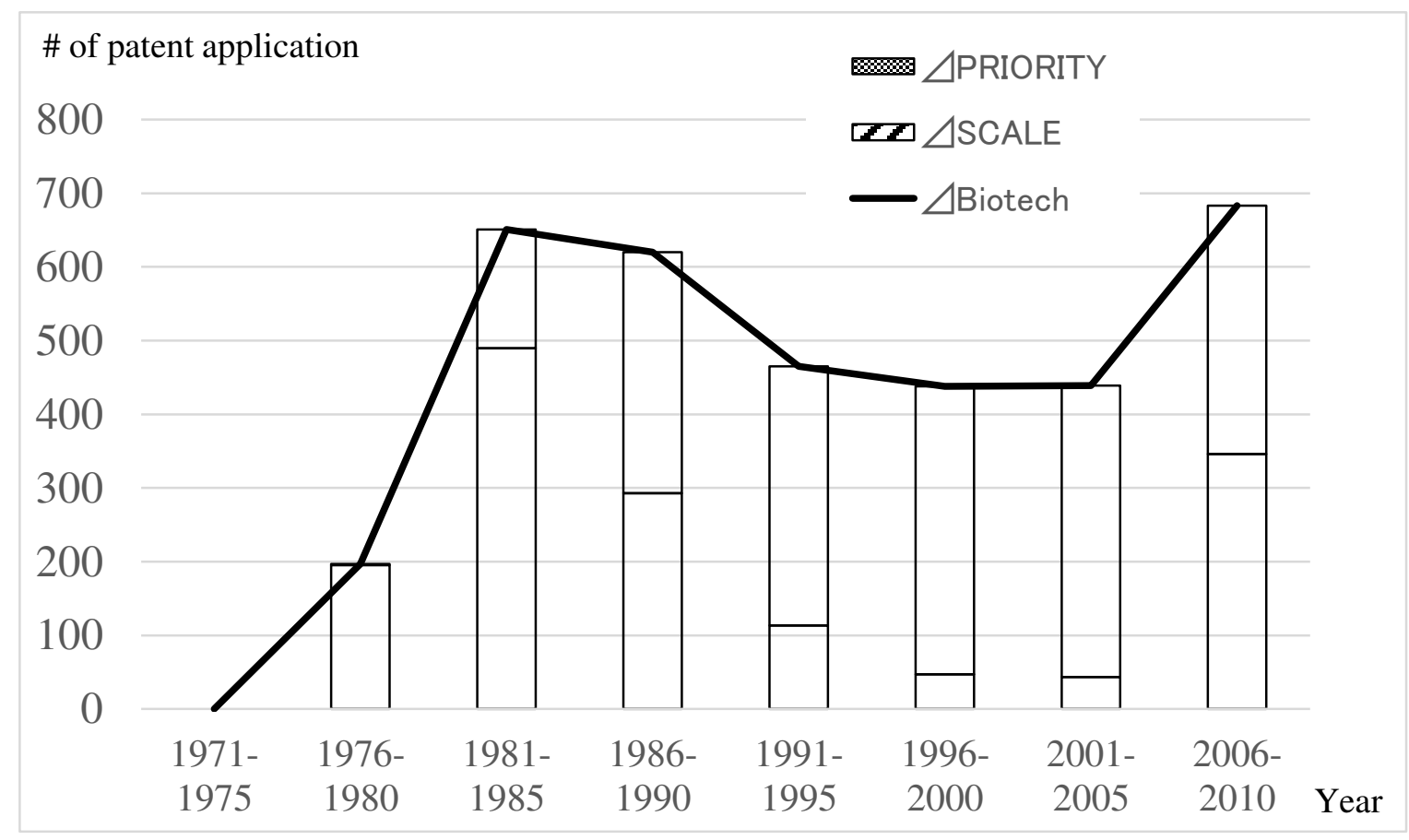

Figure 4. Decomposition analysis of patent applications on selected white biotechnology

Note: The score of the columns is standardized by setting the number of patent applications from 1971 to 1975 to zero. 


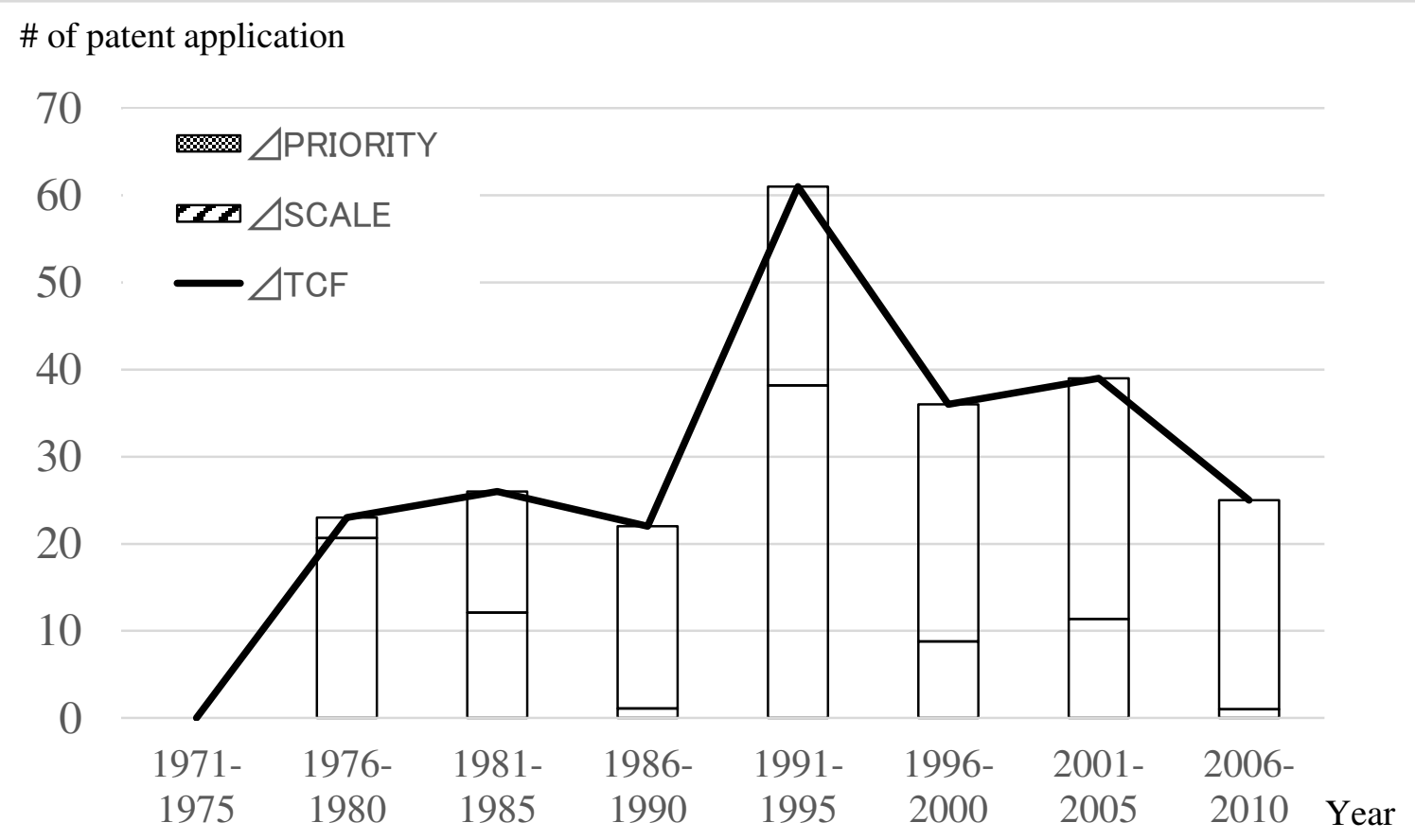

Figure 5. Decomposition analysis of patent applications on TCF bleaching technologies

Note: The score of the columns is standardized by setting the number of patent applications from 1971 to 1975 to zero. 


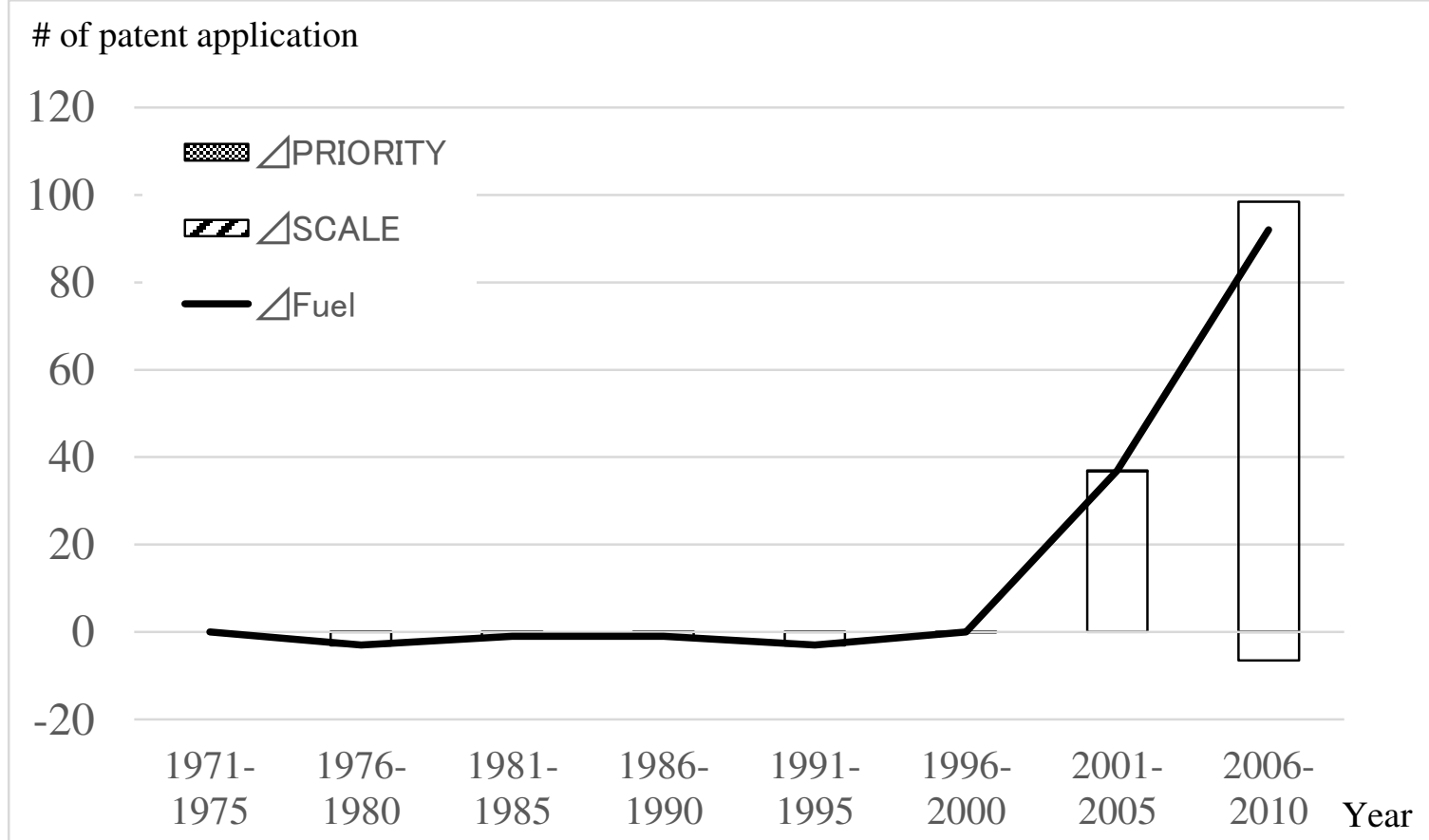

Figure 6. Decomposition analysis of patent applications on biochemical fuel cells

Note: The score of the columns is standardized by setting the number of patent applications from 1971 to 1975 to zero. 